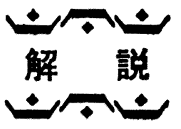

\title{
鉄および低炭素鋼の再結晶に及ぼす固溶原子 と析出物の影響
}

鈴木 木 竹 四*

Influence of Solute Atoms in Solution and Precipitates on the Recrystallization in Iron and Low-carbon Steels

Takeshi SuzukI

\section{1.はじめに}

金属の再結晶のごく初期の段階を電子顕微鏡で観察す ると，約 $1 \mu \mathrm{m}$ 以下の細かい覀結晶粒 (subgrain) が多 数見られ，その中には転位密度が非常に低いいわゆる再 結晶核が存在する. 再結晶がある程度進むとそれらの再 結晶粒は互いに衝突し粒成長は起こりにくくなるが，一 次再結晶が終了する段階では 数十 $\mu \mathrm{m}$ の再結晶粒とな る. 実に再結晶の核から出発して体積で数千倍の大きさ に成長する・多くの亜結晶粒の中に見られる再結晶核は 一見偶然に形成されるようにも見えるが，再結晶後は同 一処理に対して非常に再現性の良い結晶方位分布（集合 組織）を示す.

溶質原子および析出粒子の存在は, 最終的な再結晶組 織が形成されるまでにさまざまな影響を及ぼす。本稿で は取り扱い範囲を冷間圧延から一次再結晶まで，対象を おもに希薄鉄合金および低炭素鋼に絞つて話を進めるこ とにする．少量の溶質原子や析出粒子は巨視的に見た冷 間圧延集合組織には大きな影響を与えないと言われてい るが，再結晶の核生成が不均一に起こることを考える と, 微視的組織に与える影響を明確にすることが重要と なる・焼鈍過程では, 転位と溶質原子との相互作用, 粒 界移動に対する溶質原子の遅延効果 (Solute-drag), 析 出粒子のピン止め効果 (Zener-drag) 等を通じて再結晶 の核生成および粒成長に影響を与える。この場合，溶質 原子の拡散，偏析，他の不純物之の反応，析出粒子の 量, 大きさ, 分散形態, 熱的安定性, 析出の時期等多く の要因がかかわつてくる.さらにこれらの要因は変形マ トリックスにおいて，場所的にあるいは結晶方位学的に 不均一に作用し，それらの総合的な結果として再結晶温 度, 再結晶粒の大きさ・形態, 再結晶集合組織等が決ま つてくる.

低炭素冷延鋼板に沶いては，圧延面に平行に $\{111\}$ 面 方位が多く, $\{100\}$ 面方位が少ないような再結晶集合組 織を有する場合に良好な深絞り性を示すことが明らかに
されており1) 5)，これまでに再結晶集合組織のコントロ 一ルを目的とした膨大な研究結果が報告されている。多 数の研究結果を対象にして, 限られた紙面内で本稿のテ ーマをスマートに整理することは筆者の能力以上のこと なので, ここでは比較的少数の研究結果の紹介を通し て，鉄および低炭素鋼板の再結晶に及ぽす溶質原子およ び析出物の影響を考えてみることにする。なお再結晶集 合組織については本特集号で別に解説(伊藤：交献5))が なされているので合わせて参照されたい。また本稿に関 連する総合的な参考文献として 6)〜12) を挙げておく.

\section{2. 純鉄の再結晶に及ぼす侵入型溶質原子の影響}

Venturello, Antonione 5 ${ }^{13) 14)}$ は純鉄 $(99.995 \%$ $\mathrm{Fe})$ の回復および再結晶に及ぼす微量炭素 (G) および 微量窒素 (N) (以下 $\mathrm{C}, \mathrm{N}$ を使う) 添加の影響を調べ ている.Fig. 1 は 80\% 冷間圧延した各試片について $3 \mathrm{~h}$ の等時焼鈍を行つた場合の軟化曲線である.曲線(b) および(Cはそれぞれ 5〜86 wt. ppm C 添加試片および 120,410 wt. ppm N 添加試片についての平均的な変化

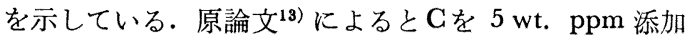

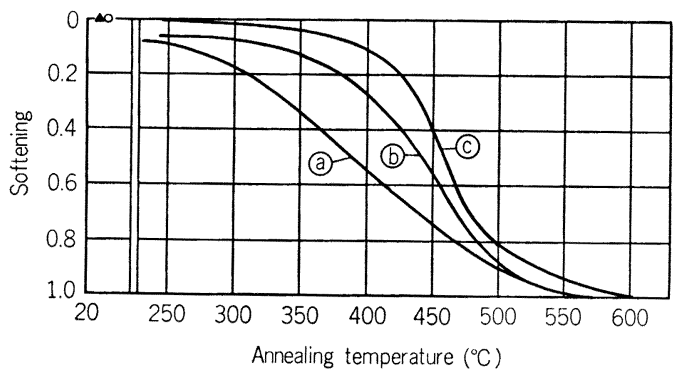

(a) pure iron (b) pure iron with additions of carbon (average of all specimens with different carbon contents) (c) pure iron with additions of nitrogen (average of all specimens with different nitrogen contents)

Fig. 1. Softening as a function of the annealing temperature (isochronal anneals of $3 \mathrm{~h}$ ). 14) 


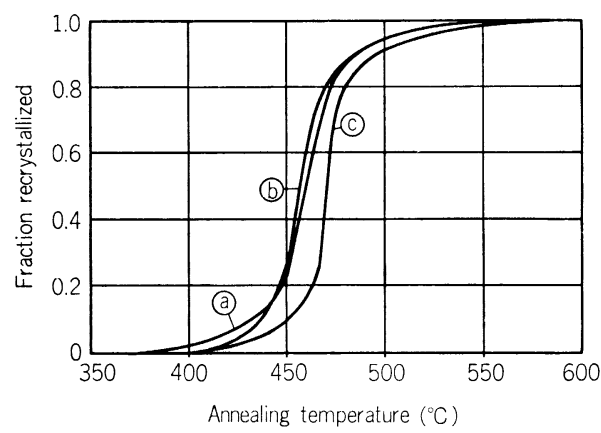

(a) pure iron (b) pure iron with additions of carbon (average of all specimens with different carbon contents) (c) pure iron with additions of nitrogen (average of all specimens with different nitrogen contents)

Fig. 2. Fraction recrystallized, as a function of the annealing temperature (isochronal anneals of $3 \mathrm{~h})$.14)

しただけで回復が抑制され，それより多くGを添加して も回復抑制の程度は変わらない.Fig. 1 によると回復 の抑制は， $\mathrm{N}$ 添加鉄> $\mathrm{C}$ 添加鉄>純鉄の順に大きい。そ の理由として, 転位と C 原子の相互作用エネルギーが約 $0.5 \mathrm{eV}$ であるのにくらべて転位と $\mathrm{N}$ 原子のそれが約 $0.75 \mathrm{eV}^{15) 16)}$ と大きいこと, およびフェライト中の $\mathrm{N}$ 固 溶量は $\mathrm{C}$ 固溶量よりも大きいことが挙げられる.

Fig. 2 は等時焼鈍過程における再結晶分率を示して おり Fig. 1 と対応する結果である. Cの添加によつて 再結晶温度はほとんど変化せず， N添加によつても 10 ${ }^{\circ} \mathrm{C}$ 程度増加するに過ぎない，この点について ANTONIONE らは， CおよびN原子の再結晶温度における易動度 は置換型溶質原子にくらべて格段に大きいこと，および 鈍鉄にくらべて回復抑制の分だけ粒界移動の駆動力が大 きくなることを指摘している。

\section{3. 純鉄および 低炭素鋼の再結晶に及ぼす置換型 溶質原子の影響}

純鉄の再結晶過程に及ぼす遷移元素添加の影響につい ては ANTONIONE ${ }^{17)}$ らが精力的な研究を行つている. 以 下にその結果の要約を述べる（文献 20）も参照). 金属 不純物の全量が 20 at. ppm 以下の素材鉄を純 Ar ガス 中でアーク溶解し, 種々の濃度に合金元素 ( $\mathrm{Ti}, \mathrm{V}, \mathrm{Cr}$, $\mathrm{Mn}, \mathrm{Co}, \mathrm{Ni}, \mathrm{Cu}, \mathrm{Ga}, \mathrm{Ge})$ を添加した後純水素中で焼 鈍し， $\mathrm{C}$ およびN含有量を $1 \sim 3$ at. ppm 以下とした. 平均結晶粒径を約 $10^{-1} \mathrm{~mm}$ とした試料を $85 \%$ 冷間圧 延し, $350^{\circ} \mathrm{C}$ から $3 \mathrm{~h} / 30^{\circ} \sim 40^{\circ} \mathrm{C}$ の等時焼鈍を行つた.

Fig. 3 は合金鉄と純鉄の $1 / 2$ 再結晶温度の差 $(\Delta T)$ と合金元素濃度との関係を示す. Fig. 4 は Fig. 3 の曲 線の初期の勾配 $\left(\Delta T / \Delta \mathrm{C}\left({ }^{\circ} \mathrm{C} /\right.\right.$ at. ppm) $)$ を合金元素 の原子番号に対してプロットした図であり, Fig. 5 は約 1000 at. ppm の合金元素を添加した鉄の $1 / 2$ 再結晶温

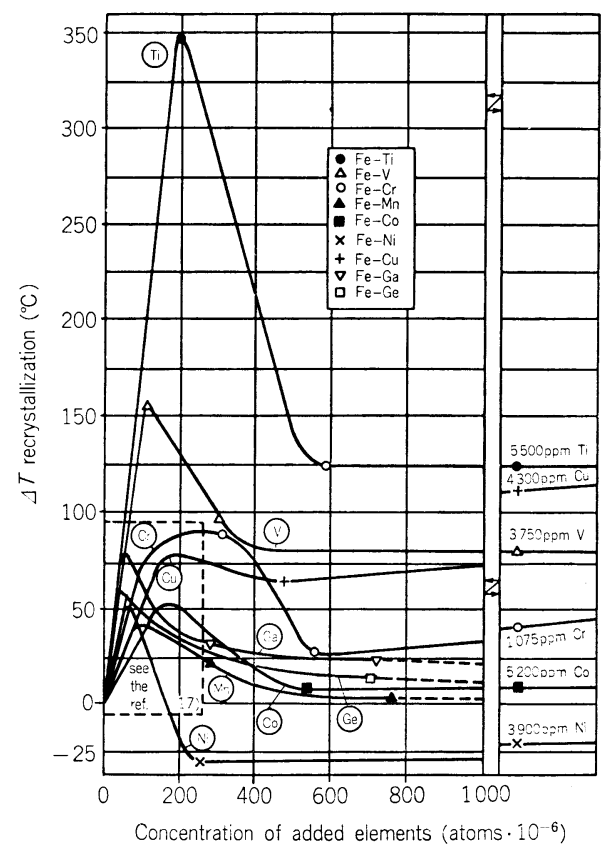

Fig. 3. Difference between half-recrystallization temperature of each alloy and half-recrystallization temperature of the corresponding pure iron, plotted against the concentration of added elements. For the data on the inside of a broken line, see the original paper. ${ }^{17}$ )

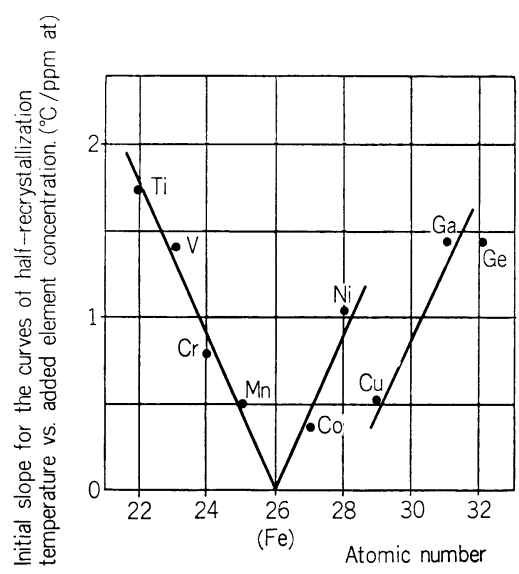

Fig. 4. Initial slopes of the curves in Fig. 3 (recrystallization temperature vs. impurity concentration), plotted against the atomic number of the alloying element. ${ }^{17)}$

度を原子番号に対してプロットした図である．Fig．3〜 5 の結果から次のような結論が得られる.

（1）純鉄の再結晶温度と遷移元素添加との関係は， およそ 50〜200 at. ppm までは再結晶温度を増加させ， 極大を示した後さらに合金元素添加量を増すと減少し, 


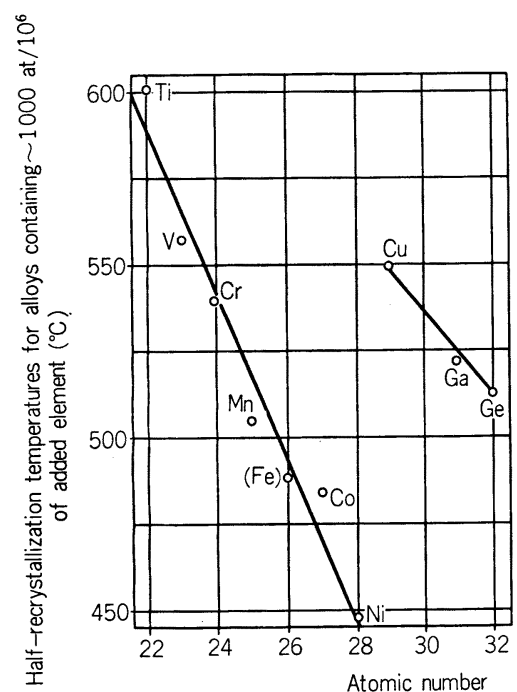

Fig. 5. Half-recrystallization temperatures of the different alloys, evaluated for added element concentrations of about 1000 at. $\times 10^{-6}$, plotted against the atomic number of the alloying element. 17)

約 500 at. ppm 以上で再結晶温度がほぼ一定になる (Fig. 3).

（2）合金元素添加量当たりの初期再結晶温度上昇量 は $\mathrm{Fe}$ から原子番号が 離れるにしたがつて大きくなる (Fig. 4).

(3) 約 1000 at. ppm の合金元素を添加した鉄の再 結晶温度は, $\mathrm{Ti}$ から $\mathrm{Ni}$ にかけて原子番号が増加する につれてほぼ直線的に減少する。 $\mathrm{Gu}, \mathrm{Ga}, \mathrm{Ge}$ はそれと は異なる直線上を変化する (Fig. 5).

上記 (1)から ( 3 )の結論について彼らは次のよらな説 明を与えている. 合金元素添加量が少ない範用での再結 晶温度上昇の原因は溶質原子の遅延効果†による. 合金 元素量が多くなつてくると，冷間加工に打ける stored energy の増加, それによる粒界移動の駆動力の増加も 一部考慮する必要がある. 合金元素濃度が高い範囲での 再結晶温度と合金元素の原子番号との関係については, 鉄の $d$ 電子結合への影響を考える必要がある．たと竞ば 鉄よりも若い原子番号の合金元素を添加する場合は, $d$ 電子結合数が増し, 鉄の自己払散の活性化エネルギーが 増加し再結晶温度が高まる. 数百 at. ppm 程度の合金 元素が鉄の自己払散に影響を与えることについては，合 金元素の粒界偏析による影響を考えている.

ANTONIONE らの研究は侵入型不純物を極めて低いレ ベルにおさえて鉄の再結晶過程に及ぼす微量溶質元素の 影響を系統的に調べており特筆される20) が，Fig. 3 の

†1固溶不純物原子の存在によつて粒界移動が著しく低下する現象は， Lücke-Stüwe-Cahn の Solute-drag 理論によつて定性的には説明 されている 12) が，どの理論が事実を正確に表現するかけついて は，まだ明らかでない（文献 7)，18，19）を参照).
ピークの存在理由に関しては明確な結論が得られていな い. 変形組織に及ぼす置換型溶質原子の影響という観点 からの研究も必要と思われる．また彼らの用いた純鉄の $1 / 2$ 再結晶温度が $476^{\circ} \mathrm{C}$ および $501^{\circ} \mathrm{C}$ とやや高い†2の も微量不純物の影響を考える上から問題が残る。

他の元素 (Y, Zr, Cb, Mo, Ru, Rh, Pd, Hf, Ta, $\mathrm{W}, \mathrm{Re}, \mathrm{Os}, \mathrm{Ir}, \mathrm{Pt}$ ) も含めた遷移元素の純鉄の再結晶 温度に与える影響については, 1960 年に ABRAHAMSON ら²4により報告されている，素材の純度に多少問題はあ るが，いずれの場合も遷移元素の添加によつて再結晶温 度は上昇する.この場合 1 at. \% 当たりの再結晶温度上 昇量の対数と外殼 $d$ 電子数との間に直線関係があること を指摘しているが，詳しい考察は行つていない。

添野ら ${ }^{25)}$ は電解鉄をベースにした 2 元合金 $(\mathrm{As}, \mathrm{Sb}$,

$\mathrm{Sn}, \mathrm{P})$ を溶製し，78\%の冷間引拔線について再結晶温 度を調べている． 合金元素添加によつて再結晶温度は $\mathrm{Sb} \approx \mathrm{Sn}>\mathrm{P}$ の順序で上昇するが，As は再結晶温度に注 とんど影響を与えない。

稲垣 ${ }^{26)}$ はりん $(\mathrm{P})$ 量を $0.002 \sim 0.2 \%$ の範囲で変え た $\mathrm{Fe}-0.02 \% \mathrm{C}-\mathrm{P}$ 合金について再結晶及び集合組織を 調べた. Fig. 6 は 70\% 冷間圧延した各合金の $550^{\circ} \mathrm{C}$ に おける再結晶核生成頻度之焼鈍時間の関係を，Fig. 7 は 同じく再結晶粒の成長速度と焼鈍時間との関係を示す. 2 つの図から明らかなように，Pは再結晶核生成及び再 結晶粒の成長を著しく抑制する．50\% 再結晶するのに 要する時間 $t_{50}$ と $1 / T$ の間の関係より見かけの活性化エ ネルギーとして $0.002 \% \mathrm{P}$ 合金で $77 \mathrm{kcal} / \mathrm{mol}, 0.024$ $0.134 \% \mathrm{P}$ 合金で約 $100 \mathrm{kcal} / \mathrm{mol}, 0.213 \% \mathrm{P}$ 合金では約 $200 \mathrm{kcal} / \mathrm{mol}$ の值を得た。これらはフェライト $(\alpha-\mathrm{Fe})$ 中の $\mathrm{P}$ の拡散の活性化エネルギー $\left.52.3 \mathrm{kcal} / \mathrm{mol}^{27}\right)$ に比 べてかなり大きい。一方 $575^{\circ} \mathrm{C}$ から焼入れた各合金の 内部摩擦測定結果によると， $\mathbf{P}$ 濃度の増加とともに固溶 $\mathrm{G}$ 濃度が減少した。これらの結果より稲垣は， $\mathrm{Fe}-\mathrm{P}$ 合 金の再結晶核の生成・成長に対して P-C complex の形 成, 熱的安定性, 変質, 崩壊が重要な役割を果たしてい ると考えている．しかし $\mathrm{P}$ と C は本来負の相互作用を持 つているので complex の形成は難しいとする意見があ $り^{28)}$, 最終的な結論を得るに至つていない。

\section{4. 低岸素鋼板の再結晶に及ぼす固溶 $\mathbf{C}$ およびセ メンタイトの影響}

低炭素鋼板における C 原子の存在状態は，冷間圧延過 程および焼鈍過程を通じて薄鋼板の再結晶集合組織形成

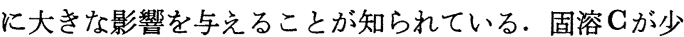

$\dagger^{2}$ ISSHIKI ら 21) は高純度鉄（残留比抵抗比 8700 ) を $30 \%$ 圧延後 $1 \mathrm{~h} / 50^{\circ} \sim 100^{\circ} \mathrm{C}$ の等時烇鍸を行い軟化過程を調へていいが，それ によると $300^{\circ} \mathrm{C}$ ですでに $70 \%$ 以上の軟化を示している. TALBOT 22) も帯融精製した高純度鉄の再結晶温度は約 $300^{\circ} \mathrm{G}$ であると報 告していろ. また筆者ら ${ }^{23)}$ の行つたジョンソン・マッセー社製純 鉄 (脱炭・脱窒焼純材) $85 \%$ 圧延材の等時焼純過程 $\left(30 \mathrm{~min} / 20^{\circ}\right.$ C) の実験によつても，400\% $\mathrm{C}$ までに $80 \%$ 以上の再結晶が起てつ ている. 


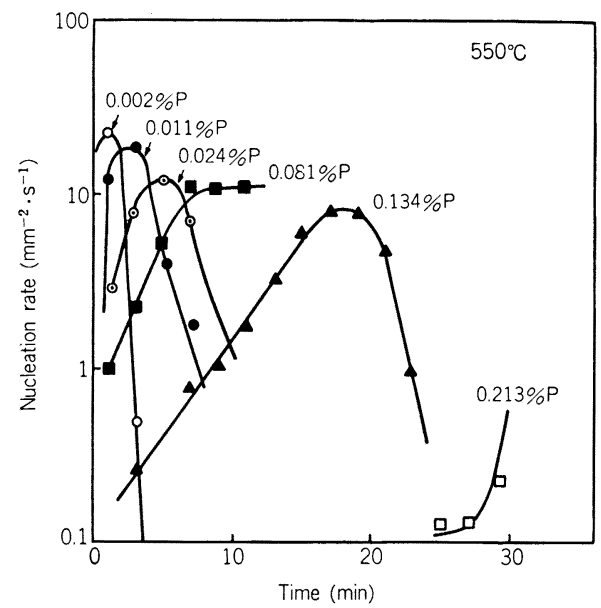

Fig. 6. Effect of $\mathbf{P}$ on the nucleation rate of new grain on annealing isothermally at $550^{\circ} \mathrm{C}$. Data obtained on $70 \%$ rolled $\mathrm{Fe}-0.02 \% \mathrm{G}-\mathrm{P}$ alloys. ${ }^{26)}$

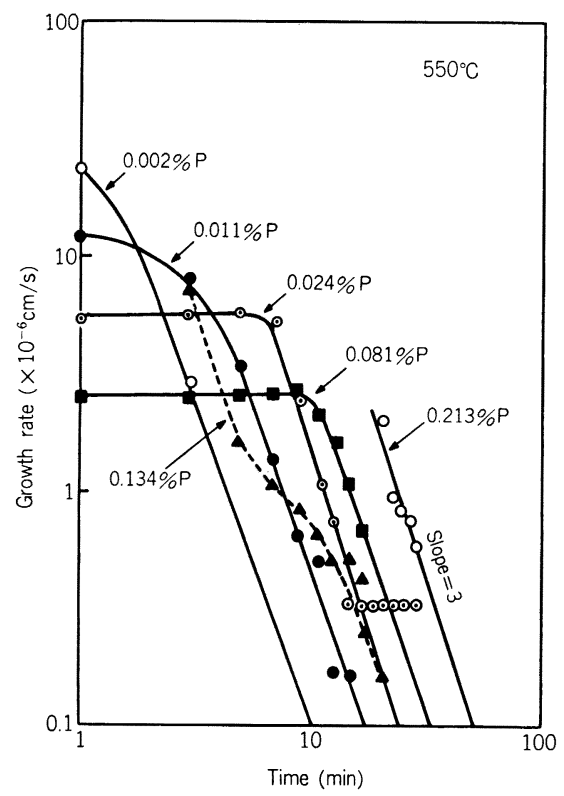

Fig. 7. Effect of $P$ on the growth rate of recrystallized-grain on annealing isothermally at $550^{\circ}$ C. Data obtained on $70 \%$ rolled $\mathrm{Fe}-0.02 \%$ C-P alloys. ${ }^{26)}$

ないほど $\boldsymbol{r}$ 值が高く深絞り性が良好になるといら点では 結論が一致しているが， C が生産工程のどの段階に主と して影響を与えているかについては研究者により見解が 分かれている。この問題を考えるには冷間圧延組織への 影響及びセメンタイトの溶解過程を調べる必要がある.

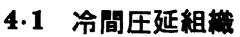

再結晶粒の核は局所的不均一変形の起きた領域, すな わち変形帯, せん断帯, 粒界や大きい分散粒子のまわり
に生じやすい(5)12)．したがつて変形組織のあり方は再結 晶集合組織形成に影響を与える.冷間圧延組織に及ぼす 固溶 $\mathbf{C}$ の影響は次のようにまとめられる.

（1）固溶 Gは転位の運動に対し障害となり，交叉す ベりまたは他すべり系の活動をうながし冷間圧延安定方 位への集積を弱める ${ }^{29}$ (30) 31).

（2）固溶 $\mathrm{C} か ゙$ 存在すると直線的な転位の集合化が起 こり ${ }^{32)}$, 変形帯が生成されやすくなる3233) †3.

(3) 固溶 Cは転位との相互作用により, 加工中の転 位の消隇を抑制し，マトリックスの加工硬化速度を高め $ろ^{32) 36)}$. この場合, 転位の応力場で $\mathrm{C}$ 原子の短範囲規則 化が起こりそれは塑性変形中の温度上昇により助長され $3^{32)}$.

低炭素鋼板を $\gamma$ 域から焼入れた後, $200^{\circ} \mathrm{C}$ で焼むどす 場合には，セメンタイト粒子がすべりに対する障害とな り, クロスすべクの確率を高め, 冷間圧延板内の変形帯 に怙ける局所的方位分布に影響を与学る ${ }^{37)}$. 一方粗大な セメンタイトが存在する場合には, セメンタイトは破碎 され圧延方向に並び，その周辺にはボイド (void) がつ くられる，その場合セメンタイトの近傍ではマトリック スとは異なるすべり变形が行われ, 転位密度が高く, 硬 さが大きくなる ${ }^{32}$. なお変形組織と再結晶核生成の関係 については, 川崎, 松尾の解説38)を参照されたい。

\section{2 焼鈍過程}

前記 $4 \cdot 1$ 節 $(1) \sim(3)$ の結果に関連して, 冷間圧延前 の固溶 $\mathrm{C}$ 量が多くなるほど, 再結晶の核生成頻度が高く なり, 一次再結晶直後の平均粒径が小さくなる ${ }^{39)}$.

低炭素鋼の熱延板中に固溶 $\mathrm{C}$ がほとんどなくても，そ の冷間圧延板を焼鈍する過程でセメンタイトの溶解が起 こり，再結晶挙動に種々の影響を及ぼす。大橋ら 40 (1) は $0.03 \sim 0.05 \% \mathrm{C}$ を含及 $\mathrm{Mn}$ を 0.01 以下 $0.80 \%$ 飞変 えた熱延板を $950^{\circ} \mathrm{C}$ から水冷し, $350^{\circ} \mathrm{C}$ で焼もどしたも のについて $71 \%$ 冷間压延し， $5 \mathrm{~min} / 20^{\circ} \mathrm{C}$ の等時焼鈍 過程に打ける電気抵抗を測定した．その結果母板で微細 に析出していたセメンタイトは冷間圧延後の回復過程で いつたん溶解して転位の周囲に $\mathrm{C}$ 雾囲気をつくり, 転位 が消隇して回復が進行する過程で新しい粒界に再析出す ることを見出した．との場合再結晶粒成長の方位依存性 を助長し, 深絞りに好ましい一次再結晶集合組織を発達 させる.またセメンタイトの再溶解に伴う電気抵抗率の 増加量は $\mathrm{Mn}$ 量が少ないものほど大きくなることを明 らかにした.

粗大なせメンタイトを含む冷延鋼板を急熱焼鈍する場 合には, セメンタイトの周辺から多数の再結晶粒が発生 することはよく知られている(Photo. 1). しかしセメン タイト周辺に密集して発生した再結晶粒は互いに衝突し て細粒にとどまり，その後の焼鈍によつて近くのマト

$\dagger^{3}$ 冷延マトリックス内の変形帯あるいは帯状領域は $\{110\}\langle 001\rangle$ 再絬 晶粒の優先的な核生成 site であるてとが知られている34)35). 


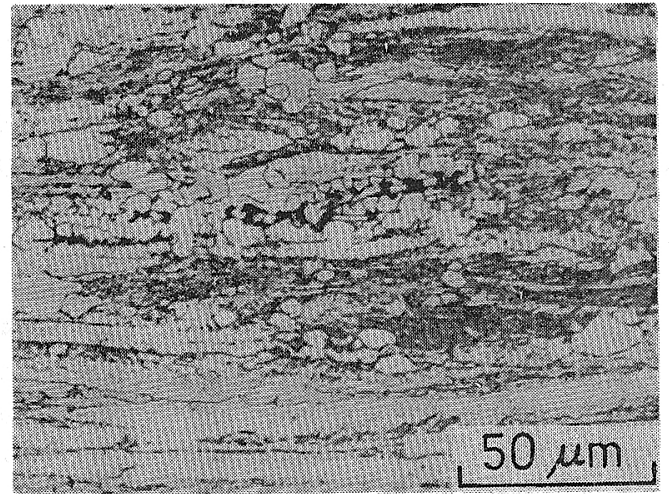

Photo. 1. Recrystallized grains first appeared around a colony of fragmented cementite particles in aluminium killed steel, cooled slowly from $920^{\circ} \mathrm{C}$, cold rolled to $75 \%$ reduction and annealed at $695^{\circ} \mathrm{C}$ for $4 \mathrm{s.42}$

リックスに発生した大きな再結晶粒によつて㫤食され 万32) 42)。

低炭素冷延鋼板を急熱焼鈍する場合，セメンタイトの 溶解乙転位密度の減少が競合して起こる。これに関連し て阿部ら ${ }^{43)}$ は低炭素 $\mathrm{Al}$ キルド鋼 $(0.046 \% \mathrm{C}, 0.35 \%$ $\mathrm{Mn})$ について，3種の熱処理を行いせメンタイトの大 きさおよび形態を変えた熱延板を $75 \%$ 冷間圧延し，そ れらを $695^{\circ} \mathrm{C}$ の塩浴中で急熱等温佬鈍する過程につい て電気伝導率 $(\sigma)$ と熱電能 $(S)$ 測定による解析を試 みた. Fig. 8 は結果の一例で, 粗大セメンタイト試料に 関する $S-\sigma$ 相関図である. 図中, $1,2,3 \cdots \cdots$ 点は $695^{\circ} \mathrm{C}$ で $1 \mathrm{~s}, 2 \mathrm{~s}, 3 \mathrm{~s} \ldots \ldots$ 等温燒鈍後焼入れた状態のデ 一タ点で， $1^{\prime} ， 2^{\prime} ， 3^{\prime} \cdots \cdots$ の点は焼入れた試片をさらに $250^{\circ} \mathrm{C}$ で $50 \mathrm{~h}$ 焼もどした状態のデータ点を示す. 点 $12^{\prime}$ は再結晶が完了乙，かつセメンタイトの析出が十分に行 われた点で, これと各データ点を結ぶ直線の勾配 $g$ 打 よびその直線の $-\Delta \sigma$ 成分が $S-\sigma$ 相関図の下に示され ている、ただし焼入れた状態の $-\Delta \sigma$ 成分は $250^{\circ} \mathrm{C} に$ おけるセメンタイト析出の勾配 ${ }^{44)} 310 \mu \mathrm{V} \cdot \mu \Omega \cdot \mathrm{cm}$. $\mathrm{deg}^{-1}$ （図中 12-12') を参考にして，固溶 $\mathrm{C}$ の奇与（図 の黒帯部) と転位密度の寄与（図の白帯部）に分けて示 してある. 図の中で勾配 $g$ の值は, 転位に偏析している G濃度に関係している，たと光ば冷間圧延状態では， $g$ $=380 \mu \mathrm{V} \cdot \mu \Omega \cdot \mathrm{cm} \cdot \mathrm{deg}^{-1}$ で高純鉄の転位に特有な勾配 $g=500 \mu \mathrm{V} \cdot \mu \Omega \cdot \mathrm{cm} \cdot \mathrm{deg}^{-1}$ 23) にくらべて相当に小さく, これは冷間圧延中にセメンタイトから解離した一部の $\mathrm{C}$ 原子が転位に偏析するためと解釈される ${ }^{45) 46)}$ 。この上ら な $\mathrm{C}$ 原子の転位への偏析は，七メンタイトが微細に析出 しているほど大きい. 圧延試片を $695^{\circ} \mathrm{C}$ で暁鈍するこ そによつてセメンタイトが溶解し，焼入れた状態では公 配 $g$ の值が減少して転位への C 原子の偏析量が増加する ことがわかるが，焼鈍温度に和けるG原子の偏析量はこ

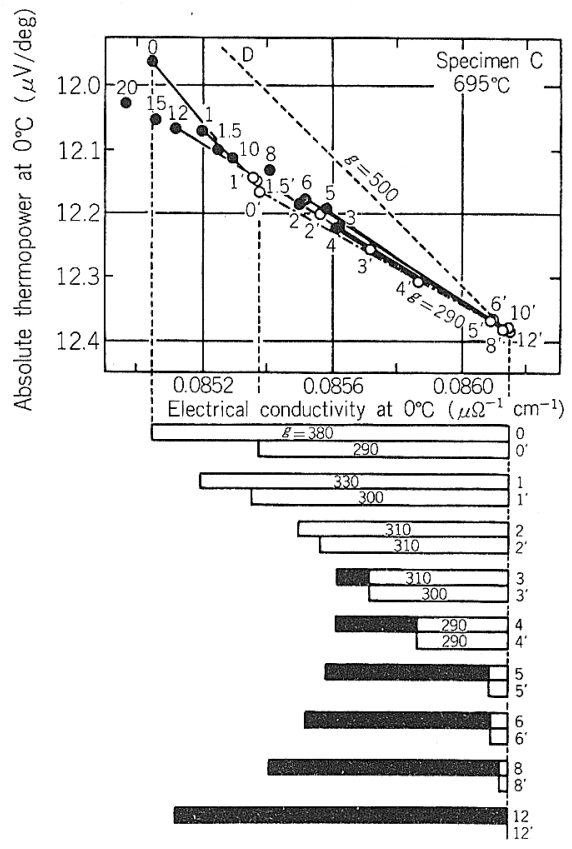

Fig. 8. Absolute thermoelectric power vs. electrical conductivitiy plot and the diagram showing conductivity differences, for specimens of lowcarbon aluminium-killed steel, cold to $75 \%$ reduction, annealed for various times at $695^{\circ} \mathrm{C}$ and quenched into iced water or tempered at $250^{\circ} \mathrm{C}$ for $50 \mathrm{~h}$ after quenching. For the detailes of the figures, see the text.43)

れよりもはるかに小さい47ことに注意する必要がある。

Fig. 8 による解析より,阿部らは熱延板に批るセメン タイトの大きさ，形態は，冷間圧延過程に打壮る $\mathrm{C}$ 原子 の転位への偏析，焼鈍途中の $\mathrm{C}$ 原子の存在量特よび $\mathrm{C}$ 原 子による再結晶前の転位消滅（回復）の抑制効果に影響 を与えると指摘している。

低炭素冷延鋼板の急熱焼鈍過程におけるセメンタイト の溶解は内部摩擦測定 ${ }^{48)}$ や電気抵抗測定 ${ }^{49) 50)}$ により調べ られているが，その溶解速度はセメンタイトが微細なほ ど，マトリックス中の転位密度が高いほど, さらにせメ ンタイト中の Mn 濃度が低いほど大きいことが報告さ れている50)51).

荒木ら ${ }^{52) 53)}$ 和よび松藤ら ${ }^{54) 55)}$ は低炭素鋼板の再結晶集 合組織あるいは $\bar{r}$ 值と固溶炭素量との相関について詳し い研究を行つている，それによると，焼鈍途中の固溶炭 素量が多くなると回復を遅らせ $\{111\}$ 面方位の再結晶粒 発達を抑制する。これに関連して岡本ら ${ }^{56)}$ は焼鈍時にお ける侵入型固溶原子 $(\mathbf{N}, \mathbf{G})$ の作用として次の 2 つを挙 げている.

（1）少量で $\{100\}$ 方位粒の再結晶を抑制し，\{111\} 方位粒の発達を促進させる。 
（2）量が多いほど $\{110\}$ 方位粒の再結晶を促進し， $\{111\}$ 方位粒の発達を抑制する. 寸なわち侵入型固溶原 子がない状態では in-situ (その場) 再結晶を起こしやす く, 侵入型固溶原子が存在する場合は, これらは転位に 偏析し, 再結晶は不均一変形部から起こり, 再結晶集合 組織形成に打壮る大傾角粒界移動の寄与が高まる ${ }^{57)}$ と述 ベている.

最近大沢ら ${ }^{58)}$ は $\mathrm{C}$ 量および $\mathrm{Mn}$ 量を変えて冷延鋼板 の $\bar{r}$ 值および集合組織を調查し， C と Mn は各々単独 よりもむしろ共存する方が $\bar{r}$ 值への悪影響が大きいこと を報告している。これはおもに回復・再結晶過程での固 溶 $\mathrm{C}$ と $\mathrm{Mn}$ の相互作用が再結晶集合組織に大きな影響 をもたらすためと考えている.なお極低炭素鋼板の再結 晶集合組織に及ぼす $\mathrm{Mn}$ と $\mathrm{N}$ 影響については, 田頭 ら59)が研究を行つている.

$\mathrm{Mn}$ とCの相互作用に関連して, 阿部ら ${ }^{60) 61)}$ は $\mathrm{Mn}$ 濃 度の異なる 4 種の低炭素 $\mathrm{Al}$ キルド鋼 $(0.05 \% \mathrm{C}, 0.1$ $1.2 \% \mathrm{Mn})$ の焼入れ時効過程 $\left(700^{\circ} \mathrm{C}\right.$ 焼入れ, $35^{\circ} \sim 250$ ${ }^{\circ} \mathrm{C}$ の 6 水準で等温時効）を電気抵抗率 $\rho$ およびマッ チーセン則からのずれ $\left(\Delta \rho=\rho 0^{\circ} \mathrm{C}-\rho_{1 \mathrm{ig} . \mathrm{N2}}\right.$ の変化 $\Delta$ $(\Delta \rho))$ の測定により調べた. その結果, 時効に伴い $\Delta$ $(\Delta \rho)$ はn $0.1 \%$ の鋼では減少するが，Mn 0.4\% 以 上の鋼では逆に増加すること扰よ゙゙その増加量は $\mathrm{Mn}$ 濃度が高くなるほど大きくなることを見出した。この結 果より焼入れ状態で Mn-G dipole が存在し, それが時 効とともに分解するといら考察を与えた. このような侵 入型溶質原子と置換型溶質原子との相互作用, それによ る再結晶への影響については, 今後さらに追究していく 必要があると思われる.

\section{5. 低炭素鋼板の再結晶に及ぼす析出物の影響}

一般に材料中に微細な分散粒子が狭い間隔で存在する 場合には，それを冷間加工後焼鈍するとき，析出粒子を 含まない場合にくらべて再結晶が抑制される. その原因 としては, 分散粒子により冷間加工中のセル形成が阻止 されることおよび結晶粒の粒界移動が阻止されることが 挙げられる7). 微細な分散粒子による粒界の拘束力は次 のような $C$. ZENER の式62) で近似される ${ }^{\dagger}$. 半径 $r$ の 球形の分散粒子が間隔 $L$ の単純立方格子配置をとつて存 在していると仮定する場合, 単位体積当たりの粒界拘束 力 $F$ は $F=\left\{(3 / 4)^{2 / 3} \pi^{1 / 3} \sigma f^{2 / 3}\right\} / L=3 f \sigma / 4 r$ で表される7．ここで $\sigma$ は粒界の界面エネルギー， $f$ は 粒子の体積分率である. 上式によると, 一定量の分散相 を含有する場合には，その分散相が微細であるほど粒界 拘束力が高まる. また $\sigma$ の大きい大傾角境界は析出相に よつて強く拘束されることになり, 再結晶集合組織形成 の一つの要因となる5). 以下では析出物ごとに幾つかの

†分散微粒子による back stressなどを考慮に入れたより笅密な取り 扱いについては文献 6)，7），63）を参照のとと.
研究結果を概観する.

\section{$5.1 \mathrm{Cu}$ 析出物の影響}

低炭素鋼板の再結晶および集合組織に及ぼす $\mathbf{C u}$ 添加 の効果については阿部65)によりまとめられている. 再結 晶に及ぼす $\mathrm{Cu}$ 析出物の影響に関するその後の研究は少 数に限られるので，ここではおもに文献 65) を参考にし て概略を記す.

$\mathrm{Cu}$ は鋼中の $\mathrm{C}, \mathrm{N}, \mathrm{O}$ とほとんど化学的相互作用を もたず，低濃度ではフェライト $(\alpha)$ 中に過飽和に固溶 し, 析出は純 $\mathrm{Cu}$ に近い $\varepsilon-\mathrm{Cu}$ 粒子†5 として析出す $3^{65)}$. H. A. WRIEDT 5 ${ }^{67)}$ によるとフェライト中の $\mathrm{Cu} の$ 固溶度は $\log (\% \mathrm{Cu})=4.335-(4499 / T)\left(698^{\circ} \sim 841^{\circ} \mathrm{C}\right)$ で与えられる。たとえば $700^{\circ} \mathrm{C}$ における固溶度は約 0.52 wt. $\% \mathrm{Cu}$ である. $\mathrm{Cu}$ 添加鋼では $\varepsilon-\mathrm{Cu}$ 析出粒子 により一次再結晶は遅滞し, 再結晶粒は伸長粒となり, 低炭素 $\mathrm{Al}$ キルド鋼と似た再結晶挙動を示す. 再結晶集 合組織は，C含有量によつて非常に異なり， $\mathrm{C}<0.02 \%$ の $\mathrm{Cu}$ 添加鋼では， $\varepsilon-\mathrm{Cu}$ の析出状態を大幅に変えて も, 再結晶集合組織の変化は狭い範囲に限られる. 一方 $\mathrm{Cu}=0.5 \sim 0.6 \%, \mathrm{G}=0.05 \sim 0.06 \%$ の組成では強い集 積を持つ $\{222\}$ 再結晶集合組織が 発達することが清水 5 ${ }^{68)}$ の研究以来幾つか報告されている. $\{222\}$ 再結晶集 合組織の発達は最終焼鈍過程の昇温速度に強く依存し, $\{222\}$ 極密度と再結晶粒の平均大きさの極大がだいたい 一致することが認められている.

Photo. 2 は再結晶粒内では大きい $\varepsilon-\mathrm{Cu}$ 粒子が存在 し，変形マトリックス内では微細な粒子が転位線に沿つ て析出している様子を示している．これより再結晶粒が 成長する際に 粒界に沿つて $\varepsilon-\mathrm{Cu}$ 粒子の凝集が起こる ことがわかる.

恵良ら ${ }^{70)}$ は $\mathrm{Cu}$ 添加鋼について, $\mathrm{Cu}$ 析出に及ぼす $\mathrm{C}$ 量の影響, 再結晶集合組織に及ぼす析出処理および $\mathrm{Ni}$ 添加の影響等を調べ次のような結果を報告している.

（1） C 量が増加すると Cu の析出量が増加する.こ れは $\mathrm{C}$ 量が低い場合には析出物の方位関係が $\mathrm{K}-\mathrm{S}$ 関係 から約 70 はずれていることと関係がある。

（2）析出処理温度， $\mathrm{G}$ 量， $\mathrm{Ni}$ 量が異なるときです $\mathrm{Cu}$ 析出物の大きさが $200 \sim 300 \AA$ ，密度が約 300 個/ $\mu \mathrm{m}^{3}$ のとさに焼鈍板の $(222) /(200)$ 比が最大を示した。

（3）徐熱焼鈍では新たに数 $10 \AA$ の た. 前記(2)の $200 \sim 300 \AA$ の析出物は $\{554\}\langle 225\rangle$ 型の再結晶集合組織発達に関係し, 他方数 $10 \AA$ の析出 物は $\{111\}\langle 011\rangle$ 型の再結晶集合組織発達に関係すると 見ている。

\section{$5 \cdot 2$ AlN の影響}

Al キルド冷延鋼板の再結晶および再結晶集合組織に

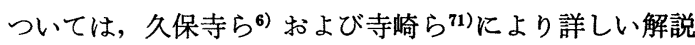

$\dagger^{5}$ けい素鋼板においては $\mathrm{Cu}_{x} \mathrm{~S}(x=1.8$ 又は 2$)$ として析出すると いわれている66). 


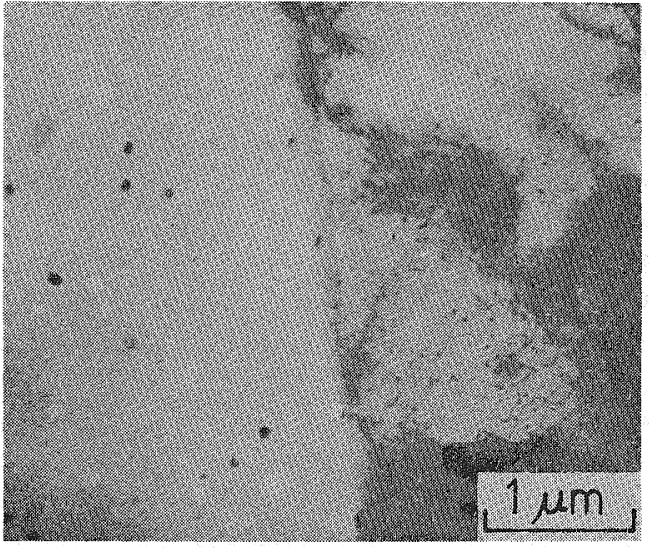

Photo. 2. Transmission electron micrograph showing globular precipitates in a recrystallized grain and fine precipitates in the deformed matrix, observed in $70 \%$-rolled copper bearing steel after annealing at $600^{\circ} \mathrm{C}$ for $54 \mathrm{~h}^{69}$ )

がされている. 寺崎らはその中で AlN の析出，集合組 織, 回復再結晶挙動, 再結晶集合組織に及ぼす椧延前析 出処理の影響の各項目について膨大な研究結果を紹介し ている. AlN 析出物によつて再結晶集合組織をコント ロールするためには，最終焼鈍の昇温速度を適切に和さ える必要がある。そのため近年開発された連続焼鈍で は，AlN 析出物による効果を有效に生かす試みはあま り行われていない状況にある。

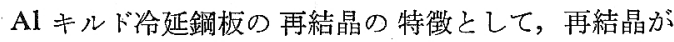
起こる以前に微細な析出物 (AIN cluster, 立方晶

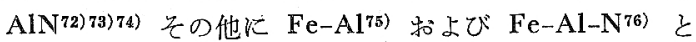
の考光るる）が存在する場合には，再結晶の核生成特 よび粒成長る抑制し，伸長再結晶粒を形成する。この場 合に集積の強い $\{111\}\langle 011\rangle$ 再結晶集合組織が得られる が， その発澾量は焼鈍過程の加熱速度77>78) や 2 段焼

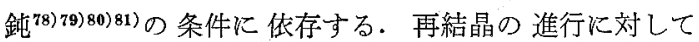
AlN 析出物の効果が有効に動く場合には, 再結晶の初期 段階から \{111\} 方位の大きさ拈よび数が他方位に比べて 勝つている.このよらな $\{111\}$ 方位粒の優位性は一次再 結晶終了後も保持される

Meyzaud ら ${ }^{85)}$ は低炭素 $\mathrm{Al}$ キルド鋼 $(0.045 \% \mathrm{G}$, $0.22 \% \mathrm{Mn}, 0.076 \% \mathrm{Al}, 0.009 \% \mathrm{~N})$ の $70 \%$ 圧延試片 について，Fig. 9 に示すよらな再結晶，A1N 析出に 関するTTT 曲線を得た。Fig.9 によるとたと学ば $650^{\circ} \mathrm{C}$ で㸉鈍する場合には，析出よりる前に再結晶が完 了して等軸再結晶粒となる．525ㅁで焼鈍する場合には 析出がまず起こり, 析出が完了してから再結晶が起こ る.この場合には伸長再結晶粒が得られる. Fig. 9 の 斜線の範囲では，析出と再結晶が競合して起こる. 彼ら は析出が完全に起こつてから再結晶が起こる場合は, 再 結晶前に転位密度がかなり減少すると述べている。そこ

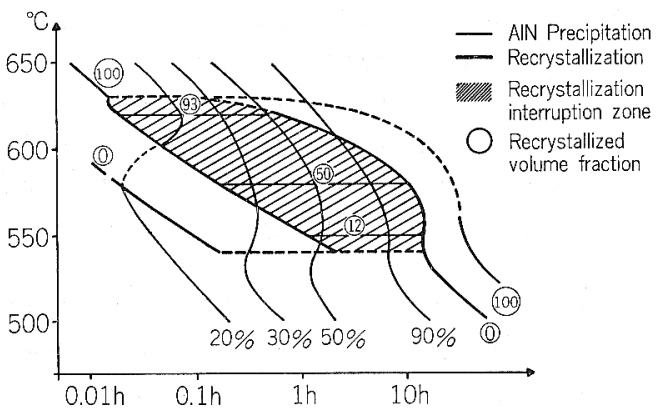

Fig. 9. Interaction between recovery, recrystallization and AlN precipitation in an aluminiumkilled steel cold rolled to $70 \%$ reduction. ${ }^{85}$ )

でこの場合亜結晶粒（subgrain）の間の丕みエネルギ一 差を無視し，亜結晶粒の大ささの違いだけに注目して， 析出物による再結晶抑制効果が覀結晶粒の方位によつて 異なる理由を次のように考察している. 同じ大きさの AIN 析出粒子 (球形) が垔粒界に均一に分布して和り, ZENER のピン止め力 ${ }^{62)}$ によつて粒界移動肪阻止されて いる場合, 粒界移動を起こすに必要な析出粒子の臨界大 きさは次式で表される. $d=\bar{D} \sqrt{f t^{2} /(2|t-1|)}$ ここで $d$ 心析出粒子の直径, $\bar{D}$ は亜結晶粒の平均大きさ, $f$ は 析出粒子の体積分率, $t=D / \bar{D}$ で $D$ 恃成長すべき粒の 大きさである. AlN 析出粒子の体積分率を $f \approx 6 \times 10^{-4}$, $t=2 \sim 3$ とし, 70\% 圧延状態の $\{111\}$ 面および $\{100\}$ 面 变形領域のセル (cell) の平均大きさを SMITH 5 ${ }^{\text {86) }}$ の值 から $\bar{D}_{(111)}=0.5 \mu \mathrm{m}$ 打よび $\bar{D}_{(100)}=0.8 \mu \mathrm{m}$ と特くと, $\{111\}$ 方位の亜粒界に対し析出物によるピン止め解除の 臨界大ささと乙て約 $170 \AA ，\{100\}$ 方位の亜粒界に対し て約 $280 \AA$ が得られる.このよらな結果から彼らはま ず $\{111\}$ 方位マトリックスで亜粒界の移動が起こり，続 いて $\{100\}$ 方位マトリックスに再結晶粒として成長して いき， $\mathrm{Al}$ キルド鋼特有の再結晶集合組織を与えると説 明している，上記の考劣をさら発展させるには，変形 マトリックスの場所による, 析出粒子の大きさ・分散状 態の不均一性, 及び亜結晶粒の大ささの不均一性を考慮 することが必要となる。

\section{$5 \cdot 3$ 岸・窒化物形成元素添加の影響}

低炭素鋼板に $\mathrm{Ti} ， \mathrm{Nb}, \mathrm{Ta}$ 等の強力な炭・窒化物形 成元素を添加することによつて，圧延面に平行に $\{111\}$ 方位が多く，\{100\} 万位が少ない再結晶集合組織が発達 することは広く知られている．炭・空化物形成元素添加 による $\bar{r}$ 值向上の原因については幾つかの考兄が提案さ れているが，須藤 ${ }^{877}$ はそれらを次の 4 つの効果に整理し ている.（1）置換型固溶原子の効果，(2) 微細析出 物 ( $\mathrm{Ti}(\mathrm{C}, \mathrm{N}), \mathrm{Nb}(\mathrm{C}, \mathrm{N}), \mathrm{Ta}(\mathrm{C}, \mathrm{N})$ 等) の効果, (3) 炭・空化物形成に伴ら固溶 $\mathrm{C}, \mathrm{N}$ 原子の掃き集め 効果,（4）副次的因子として熱延板粒度微細化効果, または熱延板集合組織を変光る效果. 


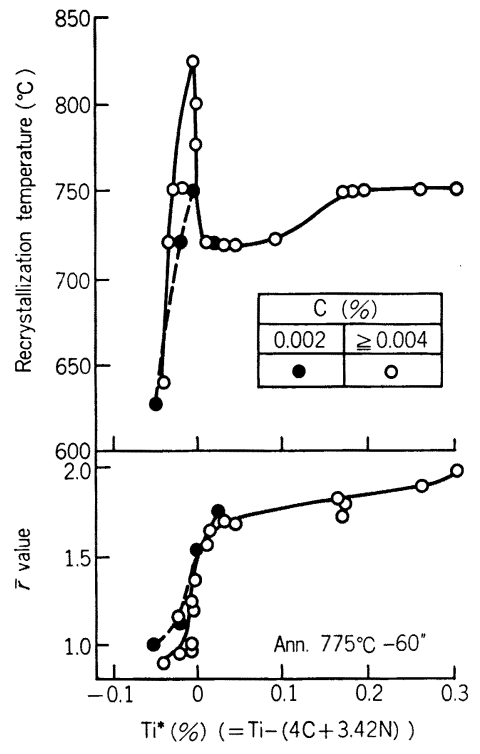

Fig. 10. Relation between $\mathrm{Ti}^{*}$, recrystallization temperature and $\bar{r}$ value in extra low G-Ti steels, cold rolled to $73 \%$ reduction and continuously annealed at a heating rate of $10^{\circ} \mathrm{C} / \mathrm{s} .{ }^{88}$ )

上記 4 つの効果の中で何が最も支配的であるかについ ては現在もな㩘論が分かれている，以下では， $\mathrm{Ti}$ 添 加低炭素鋼の再結晶過程に主眼をおいて幾つかの結果を 紹介する.

早川 ${ }^{88)}$ は極低炭素鋼 の再結晶温度及び $\bar{r}$ 值に及ぼ す Ti， C 添加量の影響を調べ Fig. 10 の結果を得た. 再結晶温度は $\mathrm{Ti}$ 添加量とともに急激に上昇するが, $\mathrm{Ti}^{*}=\mathrm{Ti}(\%)-(4 \mathrm{C}(\%)+3.43 \mathrm{~N}(\%)$ が零, すなわち $\mathbf{N}$ と $\mathbf{C}$ が化学量論的に完全に捕捉されると, 急激に低下 する.ささらに $\mathrm{C}$ 量が増すほど，再結晶温度は高くなる。 $\bar{r}$ 值は $\mathrm{Ti}^{*}$ が零近くから急激に上昇しそれ以上の $\mathrm{Ti}$ 量 で深絞り用鋼板としての特性を備えるようになる．彼ら は再結晶温度について, $300 \AA$ 以下の $\mathrm{TiC}$ 析出物の密 度とそれによる再結晶核生成の抑制効果から説明してい る. 又 $\bar{r}$ 值については， $\mathrm{C}$ と $\mathrm{N}$ 原子の掃き集め効果によ り冷間圧延安定方位が鮮鋭に発達するためとしている.

LOTTER ら ${ }^{89)}$ はあらかじめ $\mathrm{TiC}$ および $\mathrm{Nb}(\mathrm{C}, \mathrm{N})$ を微細に析出させた $\mathrm{Ti}$ 添加鋼 $(0.010 \% \mathrm{C}, 0.13 \% \mathrm{Ti})$ および $\mathrm{Nb}$ 添加鋼 $(0.008 \% \mathrm{C}, 0.0042 \% \mathrm{~N}, 0.11 \% \mathrm{Nb})$ の冷延鋼板を $590^{\circ} \sim 750^{\circ} \mathrm{C}$ の種々の温度で等温焼鈍し， \{112\} 面に関するX線 line broadening の測定より Fig. 11 の関係図を得た. Fig. 11 の直線の勾配より, $\mathrm{Ti}$ 添加鋼及び $\mathrm{Nb}$ 添加鋼の再結晶開始のための活性 化ェネルギーとしてそれぞれ 443 及び $269 \mathrm{~kJ} / \mathrm{mol}$ を得 た. 一方彼らは, 析出粒子の半径と時間の 3 乗根との間 に直線関係が成り立つとして, WAGNER ${ }^{90)}$ の液体におけ るオストワルド成長の理論を適用し, 払散支配による析

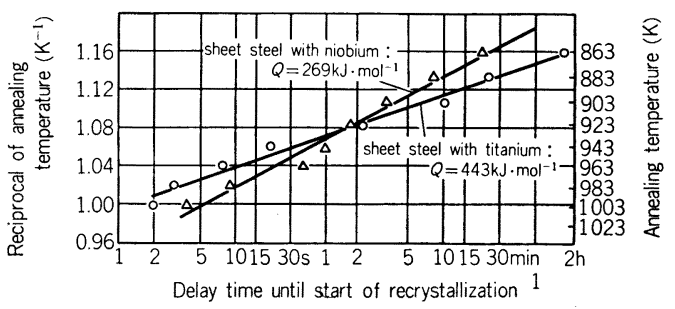

Fig. 11. Arrhenius plot for the determination of activation energies $Q$ based on the start of recrystallization in microalloyed steel sheets. ${ }^{89}$ )

出粒子成長の活性化ェネルギーとして $\mathrm{TiC}$ 及び $\mathrm{Nb}(\mathrm{C}$, N) に対してそれぞれ $Q=(368 \pm 120) \mathrm{kJ} / \mathrm{mol}$ 及び $Q=$ $(280 \pm 80) \mathrm{kJ} / \mathrm{mol}$ を得た。これらの数值が Fig. 11 で 求めた数值と誤差範用内で一致していることより, 析出 粒子がある臨界大ささ以上に成長することが，成長可能 な再結晶核生成を律速していると結論している.

筆者 ${ }^{91)}$ は $0.008 \% \mathrm{C}, 0.10 \% \mathrm{Ti}$ の $\mathrm{Ti}$ 添加低炭素鋼 熱延板を $1250^{\circ} \mathrm{C}$ から氷塩水中に焼入れ， $\mathrm{TiC}$ をほぼ 完全に固溶させた試料をべースにして，焼入れたまま， $700^{\circ} \mathrm{C}-0.5 \mathrm{~h}$ 焼もどし, $700^{\circ} \mathrm{C}-100 \mathrm{~h}$ 焼もどしの 3 種の 処理試片を $85 \%$ 冷間圧延し, $700^{\circ} \mathrm{C}$ 塩浴中での等温焼 鈍過程に打ける硬さ，再結晶分率および電気抵抗率を観 測した。その結果，焼入れたまま $>700^{\circ} \mathrm{C}-0.5 \mathrm{~h}>700$ ${ }^{\circ} \mathrm{C}-100 \mathrm{~h}$ 処理の順序で再結晶が抑制された。再結晶を 遅滞させる原因として，焼鈍の初期では固溶 $\mathrm{Ti}$ あるい は Ti-G complex†6 といつたものの効果が大きいこと を指摘した. 亜結晶粒界の移動は微細な $\mathrm{TiC}$ 析出物の 存在によつて抑制されると考えられるが，その間にも変 形マトリックス中の 転位密度は減少し続け, 実質的な 再結晶は回復が相当に進んだ状態で進行する (Fig. 12).

$\mathrm{Ti}$ 添加低炭素鋼で $\mathrm{C}$ および $\mathrm{Ti}$ の濃度が高くなると (たとえば松岡ら ${ }^{92)} の 0.06 \% \mathrm{C}, 0.35 \% \mathrm{Ti}$ )，大傾角粒界 の移動が強く抑制され，in situ 的な再結晶が起こるよう になる・

その他 $\mathrm{V}(\mathrm{C}, \mathrm{N})$ 析出物 ${ }^{93)}, \mathrm{Ta}(\mathrm{C}, \mathrm{N})$ 析出物 ${ }^{30)}$, $\mathrm{Nb}(\mathrm{C}, \mathrm{N})$ 析出物 ${ }^{94)}$ 95) む低炭素鋼の再結晶に対して, 基 本的には $\mathrm{Ti}(\mathrm{C}, \mathrm{N})$ と同様の効果を示す.

\section{6.おわりに}

本稿では比較的少数の研究結果をるとにして鉄および 低炭素鋼の再結晶に及ぼす溶質原子と析出物の影響を概 観したが，次のよらな点について，今後に研究が持ち越 されているよらに思われる。

（1） 3 章に述べたように，置換型溶質元素濃度に対

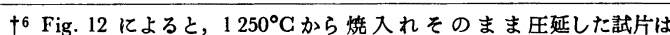
$700^{\circ} \mathrm{C}-3 \mathrm{~s}$ 焼鈍後焼入れて $250^{\circ} \mathrm{G}-50 \mathrm{~h}$ 焼もどししても電気抵抗率は 焼入れ直後とほとんど変わらなかつた. Ti の拡散速度から考えて, $700^{\circ} \mathrm{C}-3 \mathrm{~s}$ 焼鋾で $\mathrm{TiC}$ の析出が十分に起とつたとは考光奞い。 こで一つの考えとして，Ti-G complex の存在を推定した. 


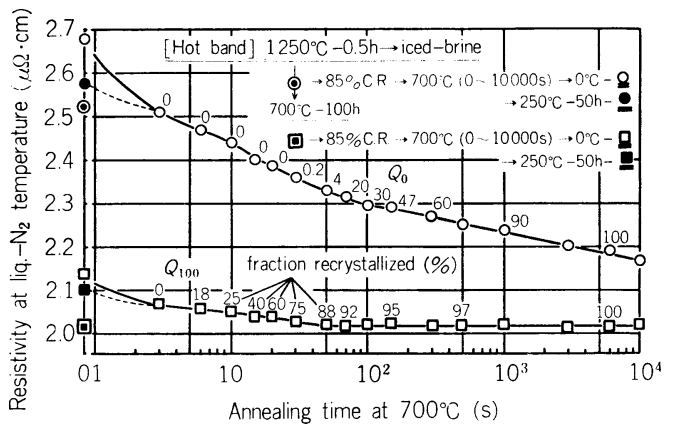

Fig. 12. Ghanges of electrical resistivity and fraction recrystallized of titanium bearing lowcarbon sheet steel during isothermal annealing at $700^{\circ}$ C. ${ }^{91)}$

して希薄鉄合金の再結晶温度にピークが生じる原因につ いては明確な説明が与えられていない。

(2) 3 章の ANTONIONE らの実験に対応する高純度 2 元鉄合金の冷間圧延組織および再結晶集合組織に及ほ 寸直換型溶質元素の影響といら観点からの系統的な研究 はまだ行われていない。

（3）低炭素鋼板の再結晶集合組織に及ぼす固溶炭素 およびセメンタイトの影響に関しては，冷間圧延組織へ の影響を重視する立場と焼鈍途中の固溶炭素が大きな影 響を与えるとする立場と 2 つの意見が平行した状態にあ る. 同様に炭・窒化物形成元素添加の影響についても統 一的な見解は得られていない。

（4）上記 (3) に関連して, 最近置換型溶質原子 $(\mathbf{M})$ と侵入型溶質原子 (I) との相互作用 (M-I dipole ある いは M-I complex) を重視する意見が出されている.

（5）低炭素鋼板においては，けい素鋼板における Goss texture $(\{110\}\langle 001\rangle)$ や高圧延した銅板の Cube texture $(\{100\}\langle 001\rangle)$ のよらに特定方位に非常に強い 集積を持つ再結晶集合組織は得られていない。実用とは 別に, 多結晶で析出物等の効果を利用して集積の非常に 強い再結晶集合組織を得ることも一つの夢と思われる.

（6）自動車用薄鋼板としては，深絞り性以外に多く の特性が必要とされ, 総合的な特性の向上という観点か ら研究が行われている. 現時点でそれらの特性は相当に 高いレベルにある.

（7）これをさらに前進させ新たな展望を切り開いて いくためには, 基礎的な研究, 系統的な研究の充実が必 要とされる. これに関連するものとして鉄鋼協会では, 1984 年に 2 つ委員会 (鉄鋼基礎共同研究会・高純度鋼 部会および低炭素鋼板研究委員会）が発足した。これら の研究会を基にして, 鉄及び鉄合金の再結晶に関する研 究が基礎及び応用の面で一層発展することが望まれる.

$$
\text { 交献 }
$$

1) $R . S$. Burns and $R$. H. Heyer: Sheet Metal Ind., 35 (1958), p. 261
2) R. L. Whiteley and D. E. Wise: Flat Rolled Products, vol. III (1962) [Interscience]

3 ) 岡本豊彦, 白岩俊男, 福田実: 住友金属, 14 (1962), p. 261

4 ) 長嶋晋一, 武智 弘, 加藤 弘: 日本金属学会 誌, 29 (1965), p. 393

5 ) 伊藤邦夫：鉄と鋼，70 (1984), p. 1878

6 ) 久保寺治朗, 稲垣裕輔: 日本金属学会会報, 7 (1968)， p. 383

7 ) 阿部秀夫：再結晶 (1969) [共立出版]

8 ) 鉄鋼薄板の再結晶及び集合組織（鉄鋼基礎共同研 究会再結晶部会編）(1974) [日本鉄鋼協会]

9 ) Textures of Materials (ICOTOM-5), ed. by $G$. Gottstein and $K$. Lucke (1978) [SpringerVerlag]

10) $N$. Hansen, $A . R$. Jones and $T$. Leffers: Recrystallization and Grain Growth of MultiPhase and Particle Containing Materials(1980) [RISO National Laboratory, Roskilde, Denmark]

11) Textures of Materials (ICOTOM-6) (1981) [ISIJ]

12) 伊藤邦夫：金属学会七ミナ一「集合組織」(1981. 6 月), p. 31

13) $G$. Venturello, $C$. Antonione and $F$. BonacCorso: Trans. Metall. Soc. AIME, 227 (1963), p. 1433

14) $C$. Antonione, $G$. Della Gatta and $G$. Venturello: Trans. Metall. Soc. AIME, 230 (1964), p. 700

15) $W . R$. Thomas and G. M. Leak: Proc. Phys. Soc. (London), 68 b (1955), p. 1001

16) $A . W$. Cochardt, $G$. Sahoek and $H$. Wiedersich: Acta Metall., 3 (1955), p. 533

17) $C$. Antonione, $G$. Della Gatta, $A$. Lucci, $G$. Riontino and $G$. Venturello: Acta Metall., 18 (1970), p. 1169

18) C. J. Simpson, $W . C$. Winegard and $K . T$. Aust: Grain Boundary Structure and Properties (1976), p. 201 [Academic Press, New York]

19) M. Hillert: Met. Sci. J., 13 (1979), p. 118

20) 古林英一: 文献 8), p. 1

21) $M$. Isshiki and $K$. IgAKI: Trans. JIM., 18 (1978), p. 412

22) J. TAlbot: Recovery and Recrystallization of Metals, ed. by L. Himmel (1962), p. 269 [Interscience]

23) $H$. Abe, $T$. Suzuki and $H$. Hoshina: Trans. ISIJ, 19 (1979), p. 355

24) E. P. Abrahamson, $I I$ and $B$. S. Blakeney, Jr.: Trans. Metall. Soc. AIME, 218 (1960), p. 1101

25) 添野 浩, 土屋正利: 鉄と鋼, 56 (1970), p. 382

26) 稲垣裕輔: 鉄と鋼, 70 (1984), A 116

27) $P$. L. Gruzin and $V$. V. Murel: Fiz. Met. Metalloved, 17 (1964), p. 384

28）木村宏：日本鉄鋼協会第 107 回講演大会討論 会，文献 26）に対する討論

29) 小久保一郎, 須藤正俊, 亀野克己, 橋本俊一, 塚 谷一郎，岩井隆房: 鉄と鋼, 59 (1973), p. 469

30) 野村伸吾, 柚鳥登明, 福塚淑郎: 鉄と鋼, 61 (1975), p. 3092

31）武智 弘, 高橋延幸, 長田修次, 長尾節夫：鉄と 
鋼, 56 (1970), S 475

32) $M$. Matsuo, $H$. Hayakawa and $S$. Hayami: in 9), p. 275

33) $M$. Konishi, $T$. Obara, $T$. Tanaka and $N$. OHAshi: in 9), p. 255

34）古林英一：鉄と鋼，56(1970)，p. 734

35）橋本修，大橋延夫，藤元克己：鉄と鋼，57 (1971), p. 1167

36）松尾宗次，早川 浩，中村 哲，速水哲博：鉄と 鋼， 62 (1976), S 698

37）阿部秀夫，高木甲子雄：鉄と鋼， 57 (1971), p. 1123

38）川崎宏一，松尾宗次：鉄と鋼, 70 (1984), p. 1808

39) $J$. $J$. Lavigne, $T$. Suzuki and $H$. Abe: in 11), p. 749

40）大橋延夫，小西元幸，有馬与志広：川崎製 鉄 技 報，5 (1973)，p. 164

41）大橋延夫：文献 8), p. 23

42) 阿部秀夫, 鈴木竹四, 高木公彦：鉄と鋼，64 (1978), S 760

43) $H$. Abe, $T$. Suzuki and $J . J$. Lavigne: Trans. ISIJ, 21 (1981), p. 332

44) $H$. A $\mathrm{BE}$ and T. Suzuki: Trans. ISIJ, 19 (1979), p. 689

45) $V . N$. Gridnev, $V . V$. Nemoshkalenko, Yu. Ya. Meshrov, $V$. G. Gavrilyuk, V. G. Prokopenko and $O . N$. Razumov: Phys. Stat. Sol., 31 (1975), p. 201

46) 阿部秀夫, 鈴木竹四, 池上雄二: 日本金属学会 誌, 46 (1982), p. 835

47) 阿部秀夫：第 88.89 回西山記念技術講座（1983） （日本鉄鋼協会編）

48) P. M. Rovinson, $K . V$. Barratt and $P . N$. Richards: J. Australian Inst. Met., 7 (1962), p. 35

49) 須藤正俊, 東 正則, 石神道子：鉄と鋼, 63 (1977), S 866

50）阿部秀夫，鈴木竹四，佐久間康治：鉄と鋼，68 (1982), S 1241

51) T. Suzuki and $H$. AвE: in 11), p. 797

52）荒木健治，渡辺 馨，中岡一秀：日本金属学会講 演概要 $(1971 \cdot 10$ 月 $)$, p. 107

53）久保寺治朗, 中岡一秀, 荒木健治, 渡辺馨, 岩 瀬耕二：鉄と鋼, 62 (1976), p. 846; 安藤卓雄: 鉄之鋼， 62 (1976), p. 1917

54）松藤和雄, 下村隆良, 小林英男：日本金属学会講 演概要 (1971·10 月), p. 105

55) $K$. Matsudo, $T$. Shimomura and $O$. Nozoe: Texture of Cryst. Solids, 3 (1978), p. 53

56) 岡本篤樹, 高橋政司, 水井直光：鉄と鋼，70 (1984), A 112

57）高橋政司，岡本篤樹：鉄と鋼，64 (1978), p. 2158, p. 2167

58）大沢紘一，松藤和雄，栗原 極，鈴木輝男：鉄之 鋼, 70 (1984), S 552

59) 田頭孝介, W. B. Hutchinson and $I$. L. DillaMORE：日本金属学会誌, 46 (1982), p. 679

60) 阿部秀夫, 鉿木竹四, 岡田 進: 鉄々鋼, 69 (1983), S 1415

61）阿部秀夫，鈴木竹四，岡田 進：日本金属学会講 演概要 (1984.4月), p. 39; Trans. JIM., 25
(1984), p. 215

62) C. Zener: Private communication to $C . S$. Smith: Trans. AIME, 175 (1949), p. 15

63 ) 久保寺治朗, 中岡一秀, 荒木健治: 日本金属学会 講演概要 $(1967 \cdot 10$ 月), p. 61

64）阿部秀夫：鉄と鋼， 52 (1966)，p. 882

65）阿部秀夫：文献 8), p. 135

66) 島津高英, 筑摩顕太郎, 酒井知彦, 谷野 満: 鉄 と鋼, 70 (1984), S 568, S 569

67) $H . A$. Wriedt and $L . S$. Darken: Trans. Metall. Soc. AIME, 218 (1960), p. 30

68) 清水峯男, 高橋延幸, 未宗賢一郎：鉄子鋼, 58 (1972), S 267

69）阿部秀夫，鈴木竹四，户川史江：鉄と鋼，60 (1974), p. 217

70）恵良秀則, 清水举男, 蛭田敏樹：鉄と鋼，69 (1983), S 590

71）寺崎富久長，金子輝雄：文献 8), p. 63

72) 花井 諭, 竹本長靖, 水山弥一郎, 佐直康則: 鉄 と鋼，56 (1970)，S 179; 57 (1971), p. 386

73) $S$. Hanai, $N$. Tакемoto, $Y$. Mizuyama and Y. SAzIKI: Trans. ISIJ, 11 (1971), p. 24

74）小川陸郎，福塚淑郎，八木芳郎：鉄と鋼， 58 (1972), p. 872

75）井口征夫，大橋延夫：鉄と鋼，60（1974)，S 328

76）日本鉄鋼協会鉄鋼基礎共同研究会：第 6 回再結晶 部会 (1972 年 12 月) 金属材料技術研究所・新 日本製鉄 (株) (私信)

77）清水峯男, 松倉亀雄, 高橋延幸, 品川保雄: 鉄之 鋼，50 (1964)， p. 2094, p. 2097

78) 松藤和雄：塑性と加工, 7 (1966), p. 376

79) P. N. Richards: J. Australian Inst. Met., 12 (1967), p. 2

80) 阪本喜保：日本金属学会誌，34 (1970), p. 71

81) 阿部秀夫，鈴木竹四：鉄と鋼， 56 (1970), p. 869

82) 稲垣裕輔: 日本金属学会講演概要 (1969-4 月), p. 218

83) $H$. A $\mathrm{AE}$ and T. Suzuki: Trans. ISIJ, 11 (1971), p. 201

84）寺崎富久長，金子輝雄：鉄と鋼，58（1972）, p. 1674

85) $Y$. Meyzaud and P. Parniere: Mem. Sci. Rev. Met., 71 (1974), p. 423

86) C. J. E. Smith and I. L. Dillamore: Met. Sci. J., 4 (1970), p. 161

87) 須藤正俊: 文献 8), p. 99

88）早川 浩, 古野嘉邦, 柴田政明, 高橋延幸: 鉄と 鋼, 69 (1983), S 594

89) $U$. Lotter, $W$. Muschenborn and $E$. ThieMANN: in 10), p. 133

90) C. WAgner: Z. Elektrochem., 65 (1961), p. 581

91）鈴木竹四，柳本 勝，阿部秀夫：鉄と鋼，70 (1984)，S 553

92）松岡 孝, 高橋政司: 鉄と鋼, 57(1971), p. 1134

93) 松岡 孝, 高橋政司，白石博己：鉄と鋼， 58 (1972), p. 1612

94) 秋末 治, 高階喜久男: 日本金属学会誌, 36 (1972), p. 1124

95) P. R. Mould and $J . M$. Gray: Metall. Trans., 3 (1972), p. 3121 